\title{
The impending medical revolution in haemophilia care: one patient's view
}

\section{Adam R Jones}

The history of haemophilia care has been fraught with extreme successes and epic failures. The development of plasmaderived concentrates made prophylactic treatment and home care possible, but the unintended consequences were devastating for a generation and only abated with the emergence of recombinant products. Now with the arrival of longer-acting factor concentrates and the potential offered by gene therapy, further improvements in medical and social outcomes are possible. But these new treatment approaches raise challenging ethical and moral issues that society must be prepared to confront.

Key words: haemophilia, haemophilia B, Christmas disease, gene therapy, long-acting clotting factor

I was born in April 1972. Six months later I was diagnosed with severe haemophilia $B$, which at that time was more commonly known as Christmas disease, being so named after Stephen Christmas, the first patient in whom it was described as being different from classical haemophilia (which is now known as haemophilia A) [1]. During the ensuing years I have witnessed much of the evolution of care and treatment for haemophilia in the United Kingdom.

I can recall the days when hospital admission seemed, for me at least, to be the norm rather than the exception. Many times I was placed in traction for joint bleeds especially knee bleeds, a practice that, as far as I am aware, has long been abandoned. As a child I remember when it was necessary to travel to hospital for treatment each time I had a bleed, and hoping that I would get there before the haemophilia unit closed so that my parents and I would not have to wait hours for the doctor on call to arrive. It made an incredible difference when I was allowed to begin home treatment and my mother was trained to prepare and administer my clotting factor.

I also remember the isolation I felt at school for being different to everyone else; this difference being most evident during physical education lessons where all the other boys in my class were learning how to play football, rugby, hockey, or cricket. In those years these were all games in which I was never allowed to participate for fear of injury.

The 1980s and 1990s ushered in the beginning of a

Adam R Jones, Senior Lecturer, Department of Pharmacy, Health \& Wellbeing, Faculty of Applied Science, Sciences Complex, City Campus, University of Sunderland, Sunderland, Tyne \& Wear, SR1 3SD, UK Email: adam.r.jones@sunderland.ac.uk

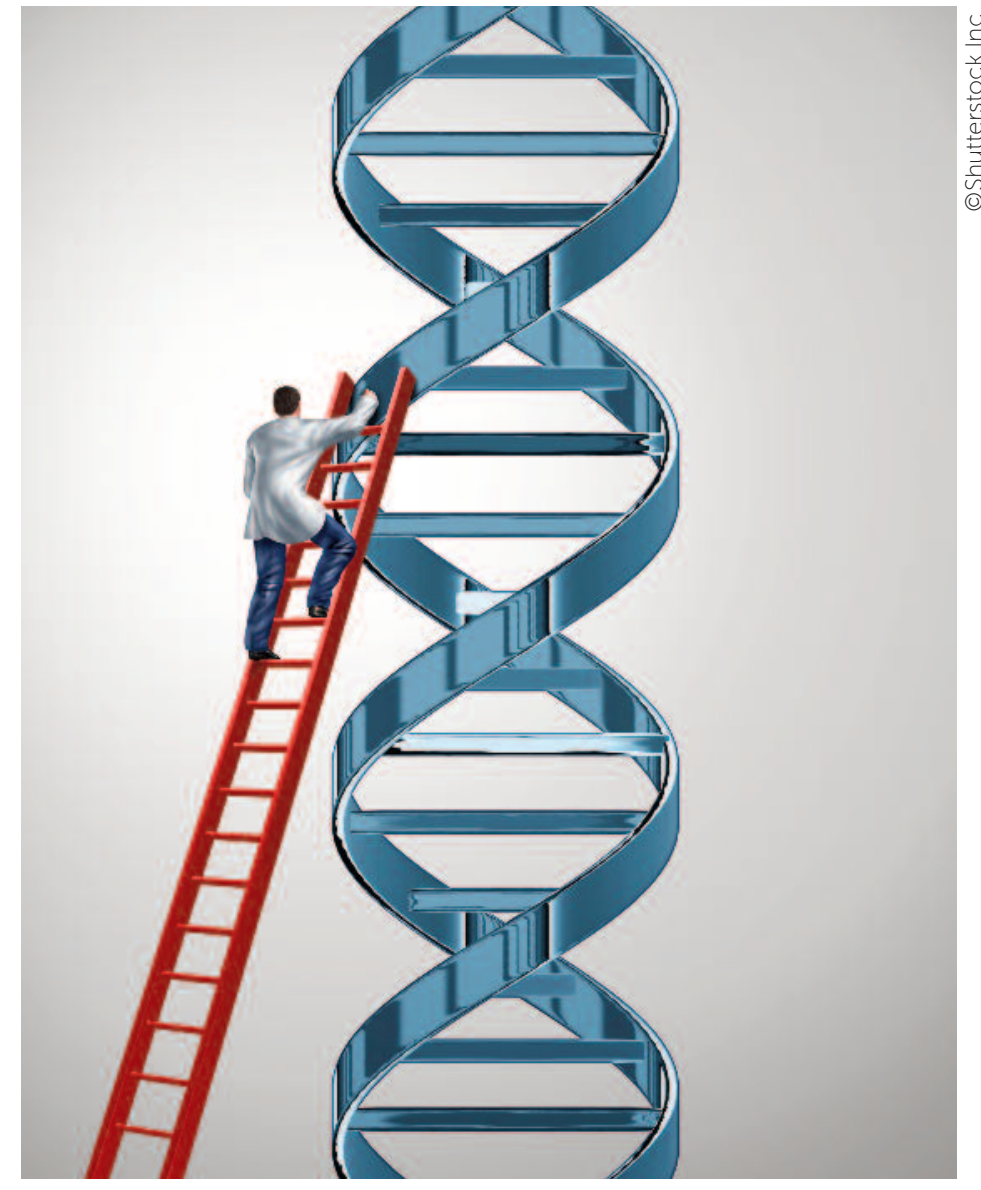

purge among the haemophilia community, with lives being lost or affected by HIV/AIDS and hepatitis C [2] through no fault of their own. Not a day goes by that I don't think of my dear friends who are still struggling with, or were unable to win the battle against these dreadful diseases, which contaminated the UK supply of blood and blood products [3]. I am one of the lucky few to come through this period of devastation relatively unscathed. I don't know how, but to this day I remain HIV negative. Maybe I am CCR5 $\Delta 32$ homozygous [4]? Even so, I have contracted both hepatitis $B$ and hepatitis $C$ through treatment with infected clotting factor IX (FIX), but on both occasions my immune system has managed to clear these viruses without the need for medical intervention (other than a liver biopsy).

\section{Enter the recombinants}

Some years later I was elated to learn that there was a new treatment, recombinant FIX (rFIX) [5], being made available, 
which removed the need for blood donors as the clotting factor was produced using microorganisms. This removed the risk of blood-borne infections ravaging the haemophilia community once more. Realising this was like being freed from a permanent tether to the angel of death, and rescue from the uncertainty of if, or when, his scythe would swing and cut me down.

Then, sometime around 2000/01 there was the setback of potential contamination of treatments with variant Creutzfeldt Jakob disease (VCJD) [6]. I received three letters from two separate haemophilia units where I had received care in the past stating that it was possible that my FIX may have come from a blood donor who had died from this spongiform encephalopathy. The first of these letters came during my final year at university, right in the middle of my dissertation!

As a result of these and other experiences, I have for many years been keenly watching for new developments in haemophilia treatment, and in my opinion we are on the verge of a medical revolution. My nephew, who lives in the USA, has been treated with a newly Food and Drug Administration (FDA) licensed rFIX product, Alprolix ${ }^{\mathrm{TM}}[7,8]$, which has a much longer half-life than the rFIX we use currently in the UK. You may think this anecdotal, but he speaks very highly of it. It has reduced his prophylaxis frequency, improving his compliance in administering his rFIX; it has reduced his frequency of breakthrough bleeding, but above all, it has provided him with an improved quality of life. So far, so good, but even better is the news that this long acting rFIX may soon be approved for use by the NHS in the UK. Which makes me think how different my life might have been had this treatment been available to my friends and I when we were younger.

Of course it is the new generation of haemophiliacs who will receive the lion's share of the benefits of this promising new treatment, such as fewer bleeds, a longer time between injections, improved social, educational, employment and sporting activity participation, along with a hopefully reduced likelihood of developing the classical haemophilic joint arthropathies [9] of the ankles, knees and elbows. I am thrilled to know that my daughter, who is a low-level carrier, has a future that is brighter and more optimistic than my past.

\section{More radical treatments}

Even though the immediate future is full of promise from the prospect of long-acting $r F I X$, there are signs that more radical treatments may soon bear fruit. This is the potential medical revolution I was referring to earlier. I am speaking of gene therapy. Do not be deterred by the nay-sayers, but neither let yourself be swept up by the folly of a silver bullet. gene therapy, in principle, works, the evidence is clear [10]. What is not yet clear is whether or not it is permanent, whether or not it can produce repeatable outcomes, and whether or not it will work in everyone. There is still much to learn about things such as which vector is most suitable for each target illness, or vector optimisation to reduce or eradicate insertional mutagenesis, but the answers are beginning to come thick and fast! There have been numerous studies over recent years [11], the most notable of which was reported in the New England Journal of Medicine in 2011 and was performed by Professor Amit Nathwani and his team [12]. A strain of virus akin to the common cold, known as adenoassociated virus serotype 8 , was genetically modified to be the vector by which the gene for FIX was inserted into the liver cells of severe haemophilia B patients. The results so far are very positive and seem to be relatively long-lasting [13]. Though none of the haemophiliacs in this study has been completely cured of haemophilia, they are all expressing levels of FIX in excess of $1 \%$, which means that they have been cured of the severe phenotype, at least for the past three years. This is a highly significant moment, and the world is, or rather should be, watching.

Of course this now raises a further question, one which society may not yet be ready to discuss or even acknowledge but which is nevertheless inescapable. Should gene therapy prove to be a viable and affordable treatment option (which I sincerely hope it will), the natural progression is to ask if it is enough for it to be used merely as a treatment strategy, much like rFIX is presently used, or if there is the confidence, will, courage, ambition, conviction, and hope (call it what you may), to make this approach to treatment more than a glorified sticking plaster. I refer now, of course, to germ-line gene therapy [14]. I can already picture the furore erupting in ethics committees across universities and health organisations (not to mention anti-genetic modification campaigners) as I write this, but this debate will happen and must happen. Momentum for this is, in my humble opinion, building as the evidence of gene therapy efficacy mounts.

\section{A conundrum for the West}

This leaves the rich Western economies with a conundrum. As treatments improve and develop for haemophiliacs living in first world economies, what will be the fate of treatment for those living in third world economies? Will personalised medicine in the West lead naturally to clotting factor (plasma derived or recombinant) becoming cheaper and more affordable for them? Will the licensing on recombinant clotting factors be relaxed so that it can be made available and affordable by local generic biopharmaceutical manufacturers for the majority of haemophiliacs worldwide who presently have little or no access to treatment? Or will the current health inequalities in worldwide haemophilia care and treatment remain, or even widen [15]? These are serious questions which we - patients, clinicians and scientists - as a community cannot ignore; and which politicians and industry must not avoid.

I look back over my past experiences of living with severe haemophilia B and see how far haemophilia care 
has come in my lifetime. With it, I also see the price the haemophilia community has paid to get here, and the price many are still paying. The legacy that will be left to future generations of haemophiliacs worldwide should be one of hope founded in evidence, if only for the sake of those who have fallen and thus helped to shape the path which has brought us to this point. This is a legacy which I never dreamed would be possible in my lifetime, but the evidence shows that it is steadily becoming an inevitable reality.

\section{A plea for humanity}

The successes of gene therapy trials in haemophilia to date leave me sitting on the edge of my seat in anticipation. Until gene therapy comes of age as a licensed and affordable mainstream treatment, the advances being concurrently made in the area of longer-acting clotting factors continues to raise the hopes and expectations of all those who rely on these medications to sustain life.

Haemophilia, it should be remembered, is not just a firstworld illness. Its effects are felt globally, and for the most

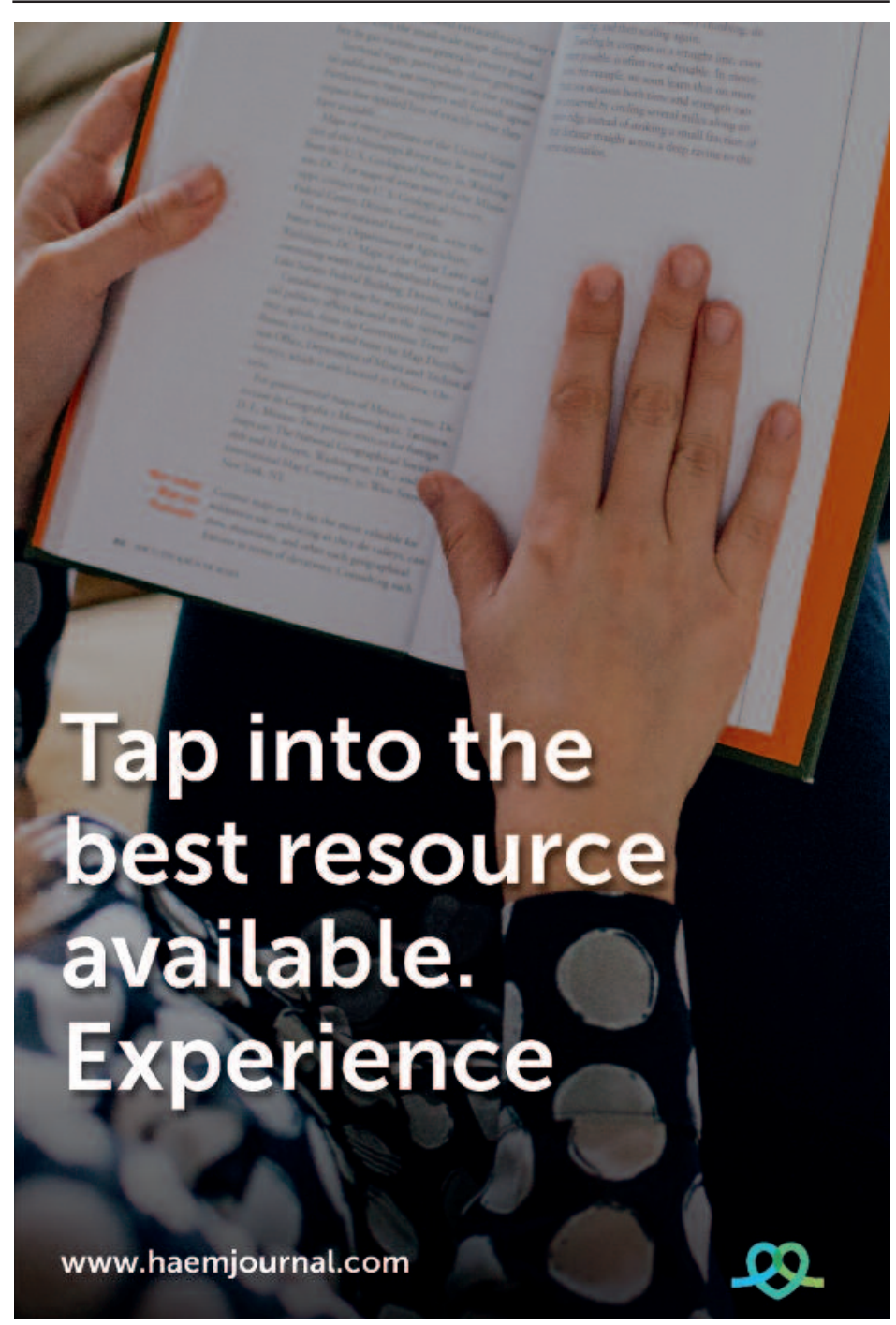

part go untreated [15]. As we hail improved medical and social outcomes through rising standards and efficacy in treatments we must not neglect the needs of those who lack these advantages purely on the basis of the political landscape and geographical location in which they were born and now live. As science and medicine advances towards a more personalised nature, we must not allow ourselves to become so overawed that we forget our humanity.

\section{Disclosures}

The author has advised that he has no interests that might be perceived as posing a conflict or bias.

\section{References}

1. Biggs R Douglas AS, Macfarlane RC, et al. Christmas Disease. BMJ 1952; 2: 1378 doi: http://dx.doi.org/10.1136/bmj.2.4799.1378

2. Darby SC, Ewart DW, Giangrande PF, et al. Mortality before and after HIV infection in the complete UK population of haemophiliacs. Nature 1995; 377: 79-82. doi:10.1038/377079a0

3. Department of Health. Government response to Lord Archer's Independent report on NHS supplied contaminated blood and blood products. London: Stationary

Office; 20 May 2009

4. Hütter G, Nowak D, Mossner M, et al. Long-term control of HIV by CCR5 Delta32/Delta32 stem-cell transplantation. N Engl J Med 2009; 360 (7): 692-8. doi 10.1056/NEJMoa0802905.

5. Roth DA, Kessler CM, Pasi KJ, et al; Recombinant Factor IX Study Group. Human recombinant factor IX: safety and efficacy studies in hemophilia B patients previously treated with plasma-derived factor IX concentrates. Blood 2001: 98(13): 3600-6.

6. Zaman SM, Hill FG, Palmer B, Millar CM, Bone A, Molesworth AM, et al. The risk of variant Creutzfeldt-Jakob disease among UK patients with bleeding disorders, known to have received potentially contaminated plasma products. Haemophilia. 2011; 17(6): 931-7. doi: 10.1111/j.1365-2516.2011.02508.x.

7. Miguelino MG, Powell JS. Clinical utility and patient perspectives on the use of extended half-life rFIXFc in the management of hemophilia B. Patient Prefer Adherence 2014; 8: 1073-83. doi: 10.2147/PPA.S54951.

8. United States of America Food and Drug Administration. FDA approves first longacting recombinant coagulation Factor IX concentrate for patients with Hemophilia B. [Online] Available from: URL

http://www.fda.gov/NewsEvents/Newsroom/PressAnnouncements/ucm391037.htm (Last accessed 12/12/2014).

9. Roosendaal G, Lafeber FP. Pathogenesis of haemophilic arthropathy. Haemophilia 2006; 12: (Suppl. 3), 117-121

10. Cancio MI, Reiss UM, Nathwani AC, et al. Developments in the treatment of hemophilia B: focus on emerging gene therapy. Appl Clin Genet 2013; 6: 91-101. doi: 10.2147/TACG.S31928.

11. High KH, Nathwani A, Spencer T, Lillicrap D. Current status of haemophilia gene therapy. Haemophilia 2014; 20 Suppl 4: 43-9. doi: 10.1111/hae.12411.

12. Nathwani AC, Tuddenham EG, Rangarajan S, et al. Adenovirus-associated virus vector-mediated gene transfer in hemophilia B. N Engl J Med 2011; 365: 2357-65. doi: 10.1056/NEJMoa1108046.

13. Nathwani AC, Reiss UM, Tuddenham EG, et al. Long-term safety and efficacy of factor IX gene therapy in hemophilia B. N Engl J Med 2014; 371: 1994-2004. doi: 10.1056/NEJMoa1407309.

14. High KA, Theodore $\mathrm{E}$. Woodward Award AAV-mediated gene transfer for haemophilia. Trans Am Clin Climatol Assoc 2003; 114: 337-352.

15. World Federation of Hemophilia. [Online]. Annual Global Survey. Available from: URL http://www.wfh.org/en/resources/annual-global-survey, (Last accessed 12/12/2014) 